\title{
THE EFFECTS OF DEFECTIVE SPATIAL STRUCTURE ON THE AGRICULTURAL PROPERTY MARKET
}

\author{
Anna Bielska, Ph.D. ${ }^{1}$ \\ Tomasz Budzyński, Ph.D. ${ }^{2}$ \\ Wioleta Krupowicz, M.Sc. ${ }^{3}$ \\ Warsaw University of Technology \\ Faculty of Geodesy and Cartography \\ Politechniki 1 Sq., 00-661 Warsaw, Poland \\ ${ }^{1}$ e-mail: a.bielska@gik.pw.edu.pl \\ ${ }^{2}$ e-mail: t.budzynski@gik.pw.edu.pl \\ ${ }^{3}$ e-mail:w.krupowicz@gik.pw.edu.pl
}

Received 23 January 2015, Accepted 27 April 2015

\begin{abstract}
Rural areas in Poland are distinguished by one of the worst spatial structures of individual land properties in the European Union. The least favourable structure occurs in the southern and south-eastern part of the country, where it results in farms losing $20-30 \%$ of their agricultural revenue. The bad spatial organisation of land is also reflected in transaction prices obtained for agricultural land. Considering criteria such as: land management, parcel area, width, and elongation (length to width ratio), and soil bonitation value, this paper determines the effect of each of the criteria separately on the development of transaction prices of agricultural land in the years 2009-2014 in selected villages in the southern part of the Cegłów (Mińsk district, Mazowieckie province), distinguished by the unfavourable spatial structure of agricultural land. Meeting this objective involved the application of the analytical capacity of the Geographic Information Systems (GIS), cadastral data base, soil-agricultural map vector, study of the conditions and directions of the spatial management of the Cegłów area, and the property price and value register. The obtained study results suggest that in areas with particularly defective spatial structure, land with parameters permitting its efficient use, i.e. with proper width and elongation is particularly valuable. Another parameter determining the level of obtained prices is the bonitation value, although it is of less importance for the analysed area than for agricultural areas with proper management conditions.
\end{abstract}

Keywords: market prices of agricultural land, defective spatial structure, statistical analyses.

JEL classification: Q120, Q150, R150. 


\section{Introduction}

In competitive markets, the prices of arable land result from income possible to obtain from it. The income depends on a number of economic, legal, and environmental factors which are different across European countries (Swinnen et al., 2008: 307). In countries which joined the EU in 2004, the prices of arable land considerably increased. In the years 2006-2013, the increase in the prices of arable land amounted to $64.5 \%$ in Hungary, $162.8 \%$ in Poland, $183.1 \%$ in the Czech Republic, $225.6 \%$ in Lithuania, and as much as $263.8 \%$ in Slovakia. In the same period, particularly depending on the state of the economy of a given country, the prices of arable land decreased - by $56.8 \%$ in Ireland and by $7.1 \%$ in Spain, or slightly increased by $4.1 \%$ in Belgium or $21.4 \%$ in Italy. Substantial increases in prices only occurred in the Netherlands by $66.8 \%$, and Germany - by $83.9 \%$ (Report of Bank BGŻ, 2015).

The prices of Polish arable land are considerably lower in comparison to the majority of countries of Western Europe. In Poland in 2013, 1 ha of arable land cost 6,275€ on average, whereas in the Netherlands it cost $52,100 €$, in Italy $19,300 €$, in Germany $16,381 €$, and in Spain 9,663 €. Among countries of Eastern-Central Europe, higher prices are obtained in Poland than in countries such as the Czech Republic - 4,600 €, Slovakia - 3,700€, Hungary 2,550 €, or Lithuania - 2,390€ (Report of Bank BGŻ, 2015).

Land property has been considered to be a good investment and capital investment in Poland over the last several years. In 2016, after the expiry of the 12-year period of protection for the free circulation of arable land, dynamic development of the market with the participation of foreign investors is probable. This will contribute to the further increase in the prices of arable land.

Unfortunately, the fragmentation, elongation, and co-ownership of arable plots constitute a serious issue in certain areas of Poland. The factors negatively affect their attractiveness and therefore their price (Ciaian et al., 2012: 23).

The development of rural areas is of key importance in Poland. It concerns $93.1 \%$ of the area of the country with a population of approximately 15 million (Central Statistical Office, 2013: 27). The incorporation of Poland into the structure of the European Union, and including Polish agriculture and Polish rural areas in instruments providing support in the framework of the Common Agricultural Policy, provided a unique chance for the complex, rational solving of a number of problems related to the existing state of the economic and spatial conditions of land management and life in rural areas. A positive and optimistic character of transformations can be observed in the structure of Polish agriculture, suggesting a gradual consolidation of agricultural 
land. The average total area of an agricultural property used for agricultural activity increased from 7.8 ha in 2002 to 10.5 ha in 2012, with a simultaneous increase in its mean area of arable land from 7.0 ha to 9.3 ha (Central Statistical Office, 2014: 419). Many of them, adjusting to European Union standards, underwent the process of specialisation and modernisation. A high number of the smallest and economically weakest properties had to stop their activities or replace them with non-agricultural business.

The new reality also has an impact on the quality of agricultural land. New legal regulations have been implemented, and the scale of transfers for agriculture has increased, resulting in the changes in prices of agricultural land and growing demand for such land (Foryś, Putek-Szeląg, 2008: 37). From the 4th quarter of 2004 to the 1st quarter of 2015, transaction prices obtained for arable land in the private sector at an annual scale increased approximately 5.3 times (The Agency for Restructuring and Modernisation of Agriculture, 2015) (Figure 1). This situation is accounted for by reasons specific to the market. They include among others benefits resulting from European Union subsidies and other forms of support to agriculture, entitlements to insurance in the farmers' social security fund (The Agricultural Social Insurance Fund), an increase in the area of properties for the purpose of increasing the profitability of agricultural production, and others, e.g. the recreational use of agricultural land with exceptional environmental or landscape values (Laskowska, 2008: 158).



Fig. 1. Mean prices of agricultural land in particular quarters in Poland Source: own elaboration.

Considering high regional disproportions in the arable land structure of agricultural farms, three mega regions are distinguished in Polish agriculture (Ministry of Agriculture and 
Food Economy, 1999). The agriculture of Mega region III (including the following provinces: Kujawsko-Pomorskie, Lubelskie, Łódzkie, Mazowieckie, Podlaskie, and Wielkopolskie) is the most economically, ecologically, demographically, and socially sustainable. It includes $2 / 3$ of all of the agricultural farms in the country. Mega region II (including the following provinces: Dolnośląskie, Lubuskie, Opolskie, Pomorskie, Warmińsko-Mazurskie, andZachodniopomorskie) covers an area with the strongest land consolidation processes, as evidenced by the dominance of large agricultural farms. The least favourable structure, both in terms of area and space, occurs in the southern and south-eastern part of the country, including the following provinces: Małopolskie, Podkarpackie, Śląskie, and Świętokrzyskie (Mega region I), where it results in farms losing 20-30\% of agricultural revenues (Woch, 2006: 15). The area accumulates the most serious problems hindering the proper development of rural areas, i.e.: fragmentation the average area of agricultural farms providing agricultural activity varies from 2.4 to 5.0 ha in particular provinces - the smallest agricultural properties providing agricultural activity occurred in the Małopolskie (3.6 ha) and Podkarpackie provinces (3.7 ha); high unemployment of $30 \%$ of the total unemployment recorded in the country; and the highest percentage of farms not providing agricultural activity (in the Śląskie province amounted to $31.7 \%$, and in the Małopolskie province - 20.4\%) (Central Statistical Office, 2013: 89). Such farms are not competitive towards farms of the majority of countries of the European Union. Moreover, the defective spatial structure of a farm is frequently a serious barrier in obtaining financial support in the form of direct payments to farms or subsidies for the afforestation of agricultural land. Therefore, a priority for the development of Polish rural areas is the improvement of the spatial organisation of agricultural farms, a decrease in their number at the scale of the country, and an increase in their area. These objectives can only be met by means of consolidation work. Land consolidation is a classic legal solution aimed at the complex improvement of management conditions in agriculture and forestry. Research conducted and based on data of the Agency for the Restructuring and Modernisation of Agriculture conducted in 2013 by A Jędrejek, F. Woch, and L. Szymański (2014: 9) showed that the needs in the scope are very extensive, and were maintained at a level of approximately 7.1 million hectares, i.e. $69.14 \%$ of the area of arable land. Depending on the region, they are accordingly larger or smaller.

The regional diversity of Polish agriculture is also reflected in transaction prices obtained for arable land (The Agency for Restructuring and Modernisation of Agriculture, 2015) (Figure 2). The highest mean values in the first quarter of 2015 were obtained in the KujawskoPomorskie provinces (49,618 PLN/ha) and Wielkopolskie (47,937 PLN/ha), included to Mega 
region III. The lowest mean values were obtained in the Podkarpackie (20,850 PLN/ha) and Świętokrzyskie provinces (24,352 PLN/ha), included to Mega region I.

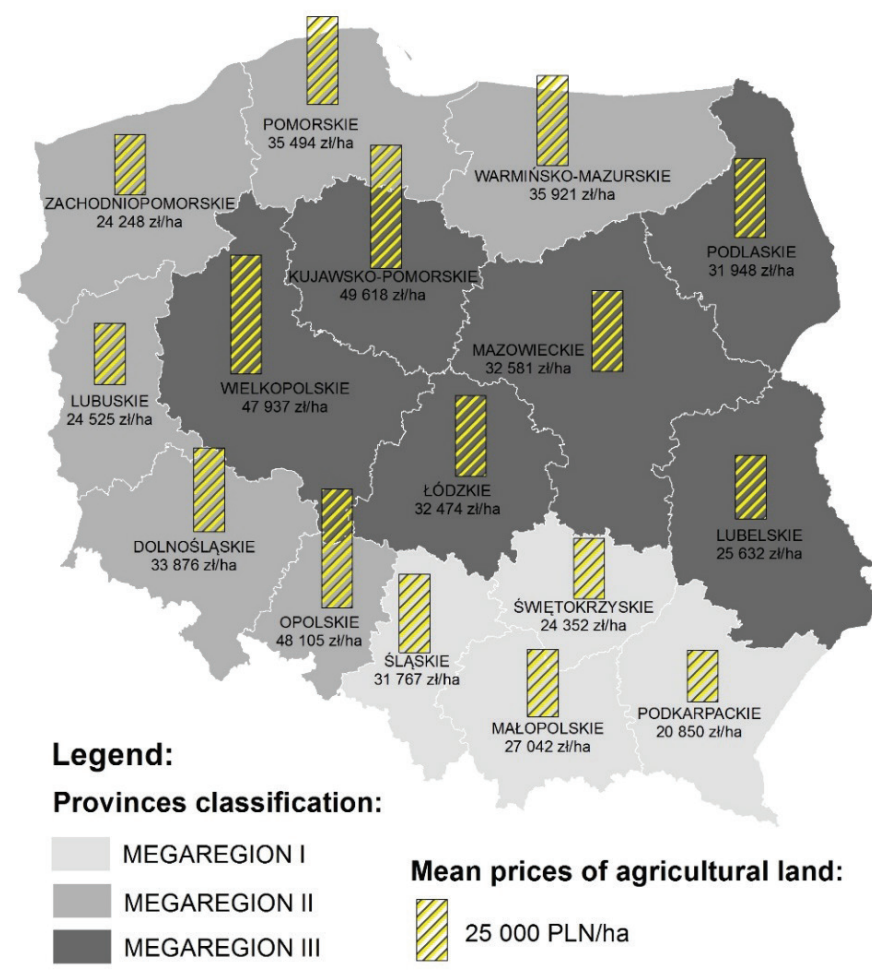

Fig. 2. Map of mega regions and mean prices of agricultural land by province in Poland (first quarter of 2015)

Source: own elaboration.

Due to the above, a number of questions arise. What is the situation of the agricultural land market in areas distinguished by the defective spatial structure of agricultural farms? What is the scale and level of the concluded transactions? Which of the discussed criteria, typical of this type of land, i.e.: land management, parcel area, width, and elongation (length to width ratio), or soil bonitation value, has a considerable effect on the level of obtained transaction prices? Is the existing space and land use structure sufficiently satisfactory to reduce the free market trading to the minimum? Or is the increased activity of purchasers observed for the purpose of an improvement of conditions of land use, involving purchasing contiguous parcels, or in 
other words, does the process of 'spontaneous land consolidation' occur? The answers to these questions constitute the subject of this article.

\section{Description of the study object in the aspect of selected parameters of agricultural properties}

The study was conducted in the area of Cegłów, Mińsk district, Mazowieckie province. The agricultural land is located approximately $15 \mathrm{~km}$ from Mińsk Mazowiecki, $50 \mathrm{~km}$ from Warsaw, and $45 \mathrm{~km}$ from Siedlce. It is typical for farmland of the Mazowsze region, where socialstructural changes occur as a result of particularly economic and social, but also environmental conditions. After the preliminary analysis of materials, the study area was selected, constituting the southern part of the area, including the following districts: Piaseczno, Posiadały, Kiczki Pierwsze, Kiczki Drugie, and Skupie, with a total area of 2.241 ha. This part of the area is a typically agricultural area with a low number of provided services. It is distinguished by the high fragmentation of farms with low production efficiency, resulting in the successive "disappearance" of the smallest ones.

Table 1. Contribution of arable land and its bonitation classes in agricultural land

\begin{tabular}{|c|c|c|}
\hline $\begin{array}{c}\text { Type of arable land } \\
\text { and its bonitation class }\end{array}$ & $\begin{array}{c}\text { Area } \\
{[\mathrm{ha}]}\end{array}$ & $\begin{array}{c}\text { Contribution in the total area } \\
\text { of the study area [\%] }\end{array}$ \\
\hline ŁIII & 9.2899 & 0.5 \\
\hline ŁIV & 56.3629 & 2.9 \\
\hline LV & 34.5359 & 1.8 \\
\hline ŁVI & 7.2351 & 0.4 \\
\hline N & 15.3626 & 0.8 \\
\hline PsIII & 1.8270 & 0.1 \\
\hline PsIV & 14.8516 & 0.8 \\
\hline PsV & 25.2744 & 1.3 \\
\hline PsVI & 1.4344 & 0.1 \\
\hline RIIIa & 0.4768 & 0.0 \\
\hline RIIIb & 130.2041 & 6.8 \\
\hline RIVa & 617.0231 & 32.2 \\
\hline RIVb & 401.0518 & 21.0 \\
\hline RV & 424.3150 & 22.2 \\
\hline RVI & 136.0912 & 7.1 \\
\hline RVIz & 38.8900 & 2.0 \\
\hline Total & 1914.2260 & 100.0 \\
\hline & & \\
\hline & & \\
\hline & & \\
\hline & & \\
\hline
\end{tabular}

Source: own elaboration based on data from the land and mortgage register. 
More than $84 \%$ of the study area constitutes agricultural land, dominated by arable land (91\% of the area). Arable land is dominated by land of moderate, weak, and very weak quality, occupying more than $92 \%$ of the area. Cultivated land included to good bonitation classes occupies an area of only approximately 130 ha, and land of the best classes RI and RII does not occur at all (Table 1).

In terms of property title, the development of 1-2 agricultural farms per area has been observed. The farms invest in e.g. livestock buildings and purchase or lease land from neighbours. As a consequence, a farm with an area of 20-30 ha is composed of a dozen to several tens of record parcels.

The study involved a detailed analysis of agricultural parcels in terms of their number, area, length, and width. The study covered 938 record units, including a total of 3,778 parcels and 83 parcels with an unidentified owner. Not all of the studied parcels are included in the agricultural farms.

The study area is distinguished by an unfavourable spatial structure of parcels. The average area of a parcel amounts to approximately 0.6 ha. Parcels with an area of up to 0.3 ha occupy $11 \%$ of the total area, but they constitute $49 \%$ of the total number of the parcels (Table 2 ).

Table 2. Structure of parcels by area

\begin{tabular}{|l|c|c|c|c|}
\hline \multicolumn{1}{|c|}{$\begin{array}{c}\text { Parcel area } \\
\text { [ha] }\end{array}$} & $\begin{array}{c}\text { Total number } \\
\text { of parcels } \\
\text { [items] }\end{array}$ & $\begin{array}{c}\text { Total area } \\
\text { of parcels } \\
{[\mathrm{ha}]}\end{array}$ & $\begin{array}{c}\text { Per cent contribution } \\
\text { in the total area } \\
\text { of parcels [\%] }\end{array}$ & $\begin{array}{c}\text { Contribution in the } \\
\text { total number } \\
\text { of parcels [\%] }\end{array}$ \\
\hline Up to 0.3 & 255 & 1,895 & 11 & 49 \\
\hline $0.3-0.6$ & 331 & 792 & 15 & 21 \\
\hline More than 0.6 & 1,656 & 1,174 & 74 & 30 \\
\hline Total & 2,241 & 3,861 & 100 & 100 \\
\hline
\end{tabular}

Source: own elaboration based on data from the land and mortgage register.

The geometry parameters of the parcels were determined with the application of the Minimum Bounding Geometry tool in the ArcInfo ESRI software. In all of the studied areas, parcels are narrow, with a width of up to $40 \mathrm{~m}-86 \%$ of the study area. As much as $11 \%$ are parcels with a width of up to $10 \mathrm{~m}$ (Table 3 ).

The elongation of the parcels, reaching 1:100 and more, is additionally unfavourable. $61 \%$ of the area is occupied by parcels with an elongation of more than $1: 20$ (Table 4). 
Table 3. Structure of parcels by width

\begin{tabular}{|l|c|c|c|c|}
\hline $\begin{array}{c}\text { Parcel width } \\
{[\mathrm{m}]}\end{array}$ & $\begin{array}{c}\text { Total number } \\
\text { of parcels } \\
{[\text { items] }}\end{array}$ & $\begin{array}{c}\text { Total area } \\
\text { of parcels } \\
{[\mathrm{ha}]}\end{array}$ & $\begin{array}{c}\text { Per cent contribution } \\
\text { in the total number } \\
\text { of parcels [\%] }\end{array}$ & $\begin{array}{c}\text { Contribution } \\
\text { in the total area } \\
\text { of parcels [\%] }\end{array}$ \\
\hline Up to 10 & 1,225 & 236 & 32 & 11 \\
\hline 10 to 20 & 1,492 & 828 & 39 & 37 \\
\hline 20 to 40 & 916 & 865 & 24 & 39 \\
\hline More than 40 & 228 & 313 & 6 & 14 \\
\hline Total & 3,861 & 2,241 & 100 & 100 \\
\hline
\end{tabular}

Source: own elaboration based on data from the land and mortgage register.

Table 4. Structure of parcels by ratio of side lengths

\begin{tabular}{|l|c|c|c|c|}
\hline $\begin{array}{c}\text { Ratio of side } \\
\text { lengths }\end{array}$ & $\begin{array}{c}\text { Total number } \\
\text { of parcels } \\
\text { [items] }\end{array}$ & $\begin{array}{c}\text { Total area } \\
\text { of parcels } \\
\text { [ha] }\end{array}$ & $\begin{array}{c}\text { Per cent contribution } \\
\text { in the total number } \\
\text { of parcels [\%] }\end{array}$ & $\begin{array}{c}\text { Contribution } \\
\text { in the total area } \\
\text { of parcels [\%] }\end{array}$ \\
\hline $1: 1-1: 5$ & 597 & 215 & 15 & 10 \\
\hline $1: 5-1: 10$ & 601 & 233 & 16 & 10 \\
\hline $1: 10-1: 20$ & 829 & 419 & 21 & 19 \\
\hline More than $1: 20$ & 1834 & 1375 & 48 & 61 \\
\hline Total & 3861 & 2241 & 100 & 100 \\
\hline
\end{tabular}

Source: own elaboration based on data from the land and mortgage register.

Parcel elongation and width are parameters considerably affecting efficient land use. The length of parcels managed by means of a tractor should amount to 250-600 m. Parcel length depends on the manner of land use (from $290 \mathrm{~m}$ is assumed for pasturelands, and up to $360 \mathrm{~m}$ for arable land). In the case of access to a road on one side, the optimum length is $300 \mathrm{~m}$, and in the case of access to roads on both sides $-600 \mathrm{~m}$. Parcel elongation (measured as a ratio of parcel width to length) affects the time of work on a parcel (turns), and amount of losses at the boundaries of a parcel. It is assumed that the optimum elongation of parcels should amount to $1: 5$, and admissible parcel elongation ranges from $1: 10$ to $1: 20$. Parcel width should not be less than $20 \mathrm{~m}$. Revenues reduction below $2 \%$ is obtained in the case of parcel width below $40 \mathrm{~m}$. The unfavourable shape of parcels affects among others the marginal zones of fields developed on balks and field boundaries, generating no revenues. It has been evidenced that losses depend on the type of land use: meadow $-10 \mathrm{~cm}$, meadow and arable land $-25 \mathrm{~cm}$, arable land - $50 \mathrm{~cm}$ (Noga, 2001). 


\section{Selection of the study sample based on data obtained from the property price and value register}

The transaction base comprises all of the identified transactions regarding undeveloped arable land in the following villages: Piaseczno, Posiadały, Kiczki Pierwsze, Kiczki Drugie, and Skupie, in the period from the beginning of 2009 to September 2014, described as agricultural areas in the study of conditions and directions of spatial management of the Cegłów area (appendix No. 1 to resolution No. XLI/204/10 of the Council of the Cegłów area of 21 October 2010), and as arable land in the land and mortgage register.

The analysis of the source materials, i.e. the cadastre data base, soil-agricultural map in the vector form, study of the conditions and directions of spatial development of the Cegłów area, ortophotomap, and property price and value register for the Mińsk district, permitted the identification, analysis, and detailed description in terms of state and market prices of a total of 99 transactions involving arable land.

Among all of the described transactions included in the property data base, the preliminary analysis identified 51 transactions in which the prices considerably varied from the actual market conditions, i.e. by more than $10 \mathrm{PLN} / \mathrm{m}^{2}$, for which special transaction conditions occurred, i.e. sale by tender, resulting in their prices not reflecting their attractiveness. The aforementioned group of transactions also included those concerning land with an interest in an access road, and those concerning land comprising several registered parcels not constituting a coherent whole. Considering the objective of the paper, it was necessary to exclude them from further research. As a consequence, a total of 48 transactions were considered. They can be described as coherent for the needs of the determination of the effect of criteria such as: land management, soil bonitation value, parcel area, width, and elongation on the prices of land in the area of the local market of the southern part of the Cegłów area. The transactions described in the further part of the publication in terms of market prices of land together with the transaction price and updated price are presented in Table 6.

\section{Analysis of the temporal variability of the level of prices}

For the purposes of the determination of the temporal variability of the level of prices for 48 transactions distinguished by the median of a unitary price of $1.50 \mathrm{PLN}, 22$ transactions were selected with recorded prices varying from 0.75 to $2.25 \mathrm{PLN} / \mathrm{m}^{2}$ and area of not less than $3,000 \mathrm{~m}^{2}$. The observation of the market in the scope of price dynamics showed that 
a change in the prices occurred in the analysed period. The linear trend expressed by equation $\mathrm{y}=0.0087 \mathrm{x}+0.09719$ (Figure 3) was adopted as the best type of trend reflecting temporal variability of prices in the period 01.2009-09.2014. The coefficient of determination for the above equation amounted to $\mathrm{R}^{2}=0.2362$, suggesting the price variability being accounted for by transaction date in $23.62 \%$. Based on the above equation, the value of the price change coefficient was determined at a level of 0.0087 , i.e. $0.87 \%$ at a monthly scale, and respectively $10.4 \%$ at the annual scale. This reflects tendencies occurring in the agricultural land market in the southern part of the Cegłów area. The growth is lower than for prices of arable land at the national scale, amounting to $17.7 \%$ annually on the average in the period $02.2009-02.2014$ according to the data published by the Central Statistical Office (The Agency for Restructuring and Modernisation of Agriculture, 2015).

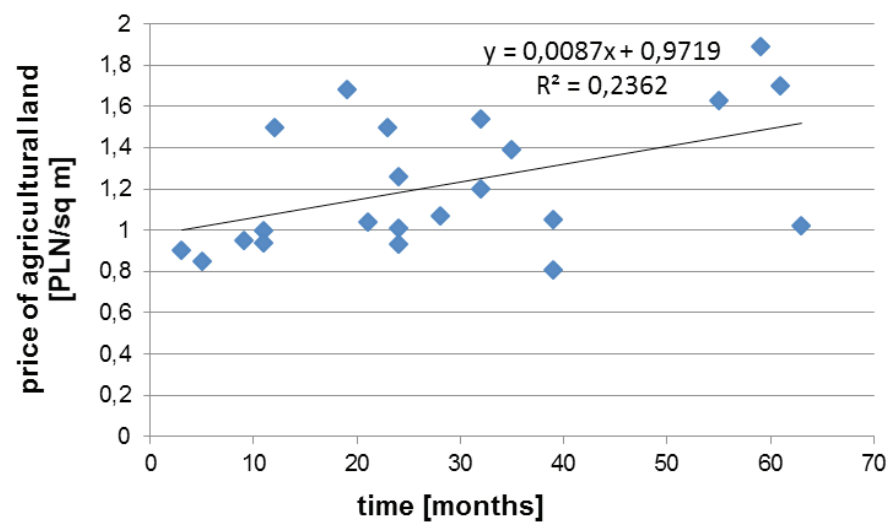

Fig. 3. Linear trend of changes in the prices of agricultural land in the Piaseczno, Posiadały, Kiczki Pierwsze, Kiczki Drugie, and Skupie villages in the period 01.2009-09.2014

Source: own elaboration based on data from the property price and value register.

Assuming an increase in prices of $0.87 \%$ at the monthly scale, updates were performed in prices included in the transaction data base (Table 6) for September 2014. The location of particular transactions providing the basis for further research is presented in Figure 4. For this purpose, transaction prices were classified by dividing them into 4 groups by means of the Natural Breaks classification method implemented in the ArcInfo ESRI software, so that similar values are included in the same range. Natural Breaks classes are based on natural groupings inherent in the data. Class breaks are identified that best group similar values and that maximize the differences between classes. The features are divided into classes whose boundaries are set 
where there are relatively big differences in the data values. This classification is based on the Jenks’ Natural Breaks algorithm (ArcGIS 10.1 Help Library).



Fig. 4. Location and level of transaction prices concerning agricultural land analysed in the period 01.2009-09.2014 in the Piaseczno, Posiadały, Kiczki Pierwsze, Kiczki Drugie, and Skupie villages

Source: own elaboration based on data from the land and mortgage register, and property price and value register.

\section{Effect of selected parameters of agricultural land on the level of obtained transaction prices}

For the purpose of determining which parameters had a considerable effect on the variability of prices of land with defective spatial structure, scales of assessment were adopted, and numerical values were ascribed to them in accordance with Table 5. The scale of assessment 
reflects the applied division, in the case of the bonitation value of soils by the Central Statistical Office. In the case of parcel area, width, and elongation, a division was applied, developed and based on long-term studies (e.g. Noga, 2001; Woch, 2013) concerning the profitability of agricultural production depending on the spatial parameters of a parcel and expertise of the authors.

Table 5. Parameters of agricultural land and scales of assessment

\begin{tabular}{|l|l|c|}
\hline \multicolumn{1}{|c|}{ Parameter } & \multicolumn{1}{|c|}{ Assessment } & Numerical value \\
\hline \multirow{3}{*}{ Land management } & uniform $-\mathrm{R}$ & 3 \\
& uniform $-€$ & 2 \\
& varied $-\mathrm{R}$ and Ps, R and $€$ or R and Ls & 1 \\
\hline \multirow{2}{*}{ Soil bonitation value } & land of moderate quality - cl. IIIb, III, IVa, IVb, IV & 2 \\
\hline \multirow{3}{*}{ Parcel areal } & land of poor quality - cl. V, VI & 3 \\
& more than 0.6000 ha & 2 \\
\hline \multirow{3}{*}{ Parcel width } & $0.3000-0.6000$ ha & 1 \\
& up to 0.3000 ha & 4 \\
\hline Parcel elongation & more than $40.00 \mathrm{~m}$ & 3 \\
(length to width ratio) & $20.01-40.00 \mathrm{~m}$ & 2 \\
& $10.00-20.00 \mathrm{~m}$ & 1 \\
\hline
\end{tabular}

Source: own elaboration.

Table 6. Transaction data base adopted in the study

\begin{tabular}{|c|c|c|c|c|c|c|c|}
\hline No. & $\begin{array}{c}\text { Land } \\
\text { management }\end{array}$ & $\begin{array}{c}\text { Soil } \\
\text { bonitation } \\
\text { value }\end{array}$ & $\begin{array}{c}\text { Parcel } \\
\text { area }\end{array}$ & $\begin{array}{l}\text { Parcel } \\
\text { width }\end{array}$ & $\begin{array}{c}\text { Parcel } \\
\text { elongation }\end{array}$ & $\begin{array}{c}\text { Transaction } \\
\text { price } \\
{\left[\mathrm{PLN} / \mathrm{m}^{2}\right]}\end{array}$ & $\begin{array}{c}\text { Updated price } \\
{\left[\mathrm{PLN} / \mathrm{m}^{2}\right]}\end{array}$ \\
\hline 1 & 2 & 3 & 4 & 5 & 6 & 7 & 8 \\
\hline 1 & 1 & 2 & 1 & 4 & 3 & 1.50 & 2.09 \\
\hline 2 & 1 & 2 & 3 & 2 & 1 & 0.81 & 1.02 \\
\hline 3 & 1 & 2 & 3 & 4 & 2 & 1.63 & 1.83 \\
\hline 4 & 3 & 2 & 2 & 3 & 3 & 1.50 & 2.24 \\
\hline 5 & 3 & 2 & 2 & 4 & 3 & 5.56 & 6.58 \\
\hline 6 & 3 & 2 & 2 & 3 & 2 & 2.73 & 4.35 \\
\hline 7 & 3 & 2 & 3 & 2 & 1 & 1.07 & 1.45 \\
\hline 8 & 1 & 1 & 3 & 3 & 1 & 3.08 & 4.45 \\
\hline 9 & 3 & 2 & 1 & 3 & 3 & 5.22 & 5.90 \\
\hline 10 & 1 & 2 & 3 & 3 & 1 & 1.68 & 2.41 \\
\hline 11 & 3 & 2 & 3 & 2 & 1 & 0.95 & 1.45 \\
\hline 12 & 3 & 2 & 3 & 4 & 3 & 6.52 & 9.36 \\
\hline 13 & 3 & 2 & 2 & 2 & 2 & 1.39 & 1.80 \\
\hline 14 & 1 & 1 & 3 & 2 & 1 & 0.42 & 0.52 \\
\hline 15 & 3 & 2 & 2 & 2 & 2 & 0.57 & 0.70 \\
\hline
\end{tabular}




\begin{tabular}{|l|l|l|l|l|l|l|l|}
\hline 1 & 2 & 3 & 4 & 5 & 6 & 7 & 8 \\
\hline 16 & 1 & 2 & 1 & 1 & 1 & 2.48 & 3.04 \\
\hline 17 & 3 & 2 & 2 & 1 & 1 & 1.00 & 1.50 \\
\hline 18 & 1 & 2 & 2 & 4 & 3 & 1.04 & 1.47 \\
\hline 19 & 3 & 1 & 2 & 2 & 2 & 1.01 & 1.41 \\
\hline 20 & 3 & 2 & 1 & 3 & 2 & 1.22 & 1.70 \\
\hline 21 & 3 & 1 & 1 & 2 & 2 & 1.38 & 1.92 \\
\hline 22 & 2 & 1 & 1 & 1 & 2 & 0.93 & 1.29 \\
\hline 23 & 3 & 2 & 3 & 3 & 2 & 1.02 & 1.07 \\
\hline 24 & 3 & 1 & 3 & 3 & 1 & 0.56 & 0.87 \\
\hline 25 & 1 & 2 & 3 & 3 & 2 & 4.41 & 6.87 \\
\hline 26 & 3 & 1 & 3 & 2 & 1 & 0.90 & 1.42 \\
\hline 27 & 1 & 1 & 2 & 3 & 3 & 0.85 & 1.33 \\
\hline 28 & 3 & 2 & 3 & 3 & 2 & 6.25 & 8.91 \\
\hline 29 & 1 & 1 & 2 & 2 & 2 & 1.26 & 1.75 \\
\hline 30 & 3 & 2 & 3 & 2 & 1 & 3.49 & 4.07 \\
\hline 31 & 3 & 1 & 1 & 1 & 1 & 3.89 & 3.92 \\
\hline 32 & 3 & 1 & 2 & 3 & 2 & 1.89 & 2.05 \\
\hline 33 & 3 & 2 & 1 & 1 & 1 & 3.00 & 4.44 \\
\hline 34 & 1 & 1 & 2 & 2 & 2 & 3.00 & 4.75 \\
\hline 35 & 1 & 2 & 3 & 2 & 1 & 1.05 & 1.32 \\
\hline 36 & 1 & 1 & 3 & 2 & 1 & 0.94 & 1.41 \\
\hline 37 & 1 & 1 & 3 & 1 & 1 & 0.56 & 0.69 \\
\hline 38 & 1 & 1 & 3 & 3 & 2 & 0.70 & 0.86 \\
\hline 39 & 3 & 1 & 2 & 3 & 2 & 0.73 & 0.90 \\
\hline 40 & 3 & 1 & 2 & 2 & 1 & 0.62 & 0.76 \\
\hline 41 & 3 & 2 & 1 & 2 & 2 & 0.59 & 0.72 \\
\hline 42 & 1 & 2 & 3 & 3 & 2 & 0.93 & 1.29 \\
\hline 43 & 3 & 2 & 1 & 1 & 1 & 2.00 & 3.10 \\
\hline 44 & 1 & 1 & 3 & 2 & 1 & 1.50 & 2.10 \\
\hline 45 & 3 & 2 & 3 & 3 & 1 & 1.70 & 1.82 \\
\hline 46 & 1 & 1 & 3 & 2 & 1 & 1.20 & 1.59 \\
\hline 47 & 1 & 2 & 3 & 2 & 1 & 1.54 & 2.04 \\
\hline 48 & 1 & 1 & 3 & 4 & 3 & 2.35 & 3.62 \\
\hline & 1 & 2 & 2 & & & \\
\hline 30 & 1 & 2 & 2 & 2 & \\
\hline
\end{tabular}

Source: own elaboration based on data from the property price and value register.

The spatial distribution of transactions by the analysed criteria is presented in Figure 5.

Next, an analysis of the correlation of selected parameters and prices was performed and based on linear correlation coefficients (Hozer et al., 2002: 82) permitting the determination of the strength and direction of the correlation occurring between them (Table 7). 

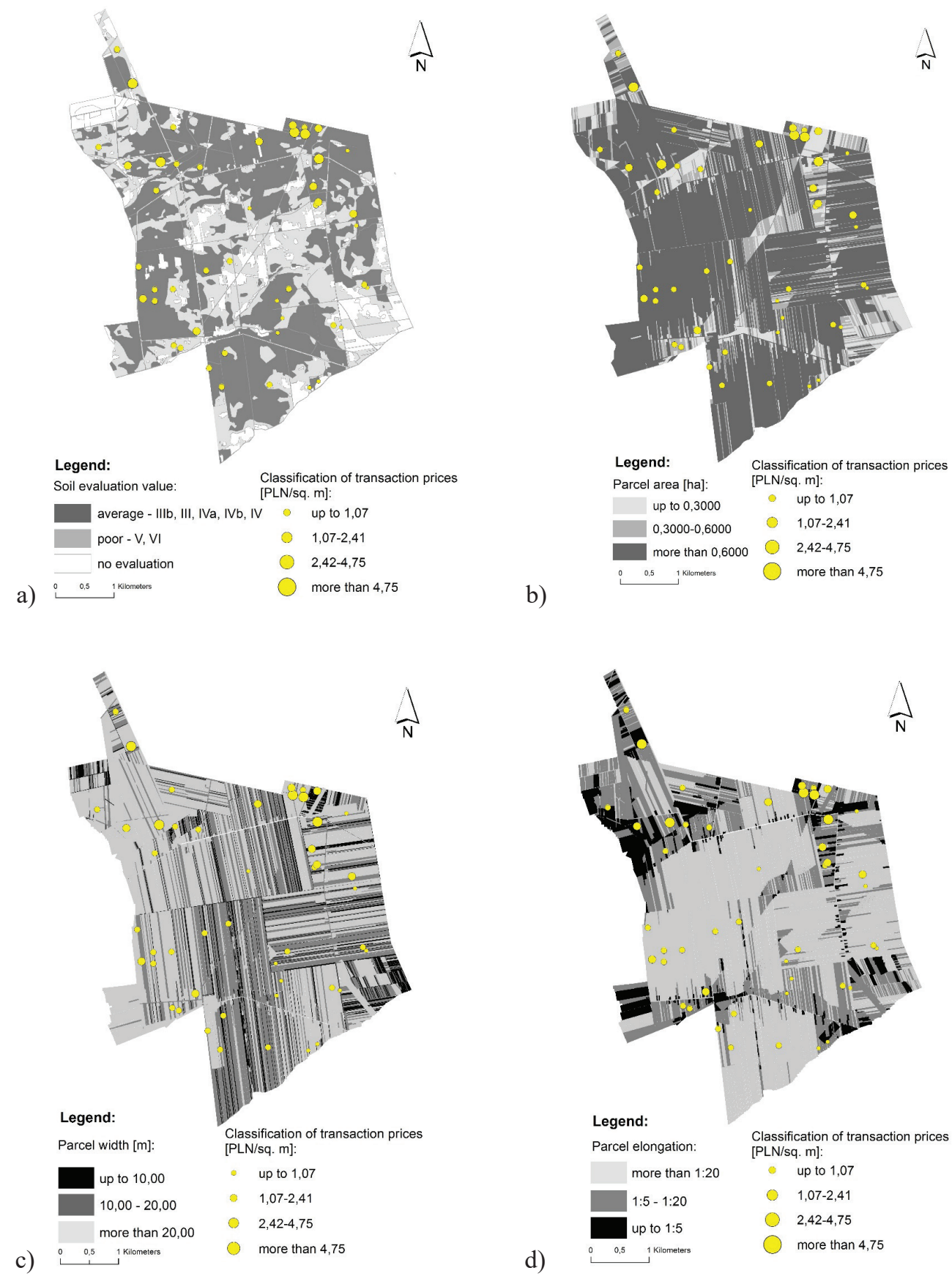

d)

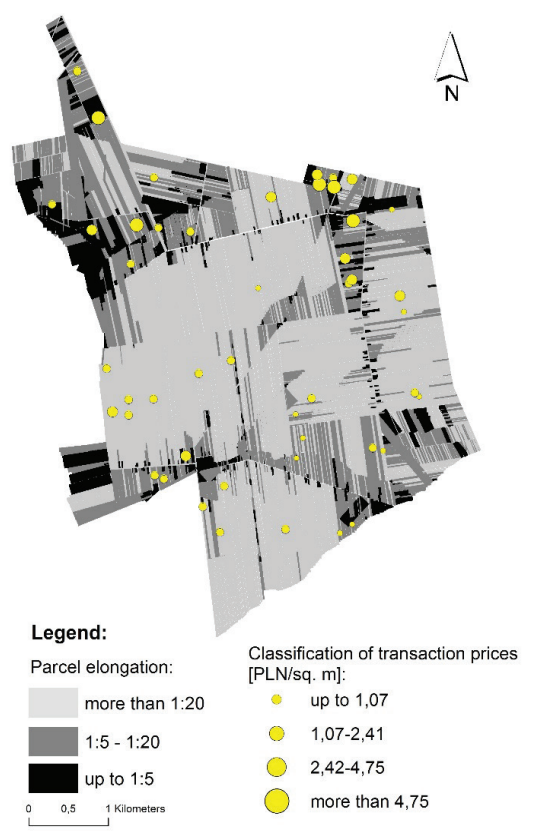

Fig. 5. Level of transaction prices concerning agricultural land and their spatial distribution in terms of the analysed criteria: a) soil bonitation value; b) parcel area; c) parcel width; d) parcel elongation

Source: own elaboration based on data from the land and mortgage register and property price and value register. 
Table 7. Matrix of linear correlation coefficients

\begin{tabular}{|l|c|c|c|c|c|c|}
\cline { 2 - 7 } \multicolumn{1}{c|}{} & $\begin{array}{c}\text { Land } \\
\text { management }\end{array}$ & $\begin{array}{c}\text { Soil } \\
\text { bonitation } \\
\text { value }\end{array}$ & Parcel area & Parcel width & $\begin{array}{c}\text { Parcel } \\
\text { elongation }\end{array}$ & Price \\
\hline Land management & 1 & 0.2183 & -0.3341 & -0.0999 & 0.0420 & 0.1562 \\
\hline Soil bonitation value & 0.2183 & 1 & -0.0624 & 0.1785 & 0.1246 & 0.2720 \\
\hline Parcel area & -0.3341 & -0.0624 & 1 & 0.2639 & -0.2843 & -0.0168 \\
\hline Parcel width & -0.0999 & 0.1785 & 0.2639 & 1 & 0.6748 & 0.2898 \\
\hline Parcel elongation & 0.0420 & 0.1246 & -0.2843 & 0.6748 & 1 & 0.3135 \\
\hline Price & 0.1562 & 0.2720 & -0.0168 & 0.2898 & 0.3135 & 1 \\
\hline
\end{tabular}

Source: own elaboration.

The analysis of the linear correlation coefficient between particular parameters and price shows that the highest value of the correlation coefficient occurs for the attributes of parcel elongation (0.3135) and parcel width (0.2898). Both of the coefficients are statistically significant at a level of significance of 0.05 . Therefore, in areas with defective spatial structure, parcels distinguished by the proper width and elongation reducing the costs of agricultural production are particularly valuable. Notice also that only a slightly lower value of the correlation coefficient occurs between the bonitation value and price $(0.2720)$, whereas the value is statistically significant at a level of significance of only 0.062 . This means that the parameter still determines the level of obtained prices, but in the case of areas with defective spatial structure, it has less effect than for land with appropriate management conditions. This fact can be accounted for by the lack of possibilities to use the full yield potential of the soil. The remaining correlation coefficients between particular parameters and price have considerably lower values. This suggests a weak effect on the variability of prices in the case of the parameter of land management (0.1562), or practically no effect in the case of the parameter of parcel area $(-0.0168)$.

The analysis of correlations between the parameters of land based on the matrix of linear correlation coefficients shows a strong correlation between parcel width and its elongation (correlation coefficient 0.6748 ). This natural correlation suggests that wider parcels also feature more favourable elongation - ratio of dimensions. A statistically significant correlation at a significance level of 0.05 , although considerably lower than the one discussed above (correlation coefficient -0.3341 ), is also observed in the case of the parameters of land management and parcel area.

Example differences in the level of obtained transaction prices for agricultural land depending on parcel width and elongation are presented in Figure 6. 
Parcel No. 49/2, Kiczki Drugie village

Area 0.3000 ha

Land management $-\mathrm{R}$

Parcel width $-32 \mathrm{~m}$

Parcel elongation $-1: 3$

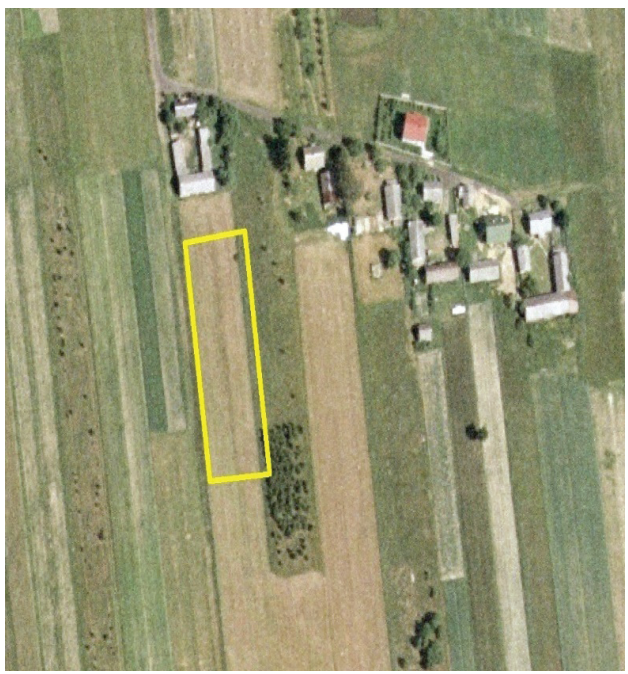

Parcel No. 331, Posiadały village

Area 1.7000 ha

Parcel width $73 \mathrm{~m}$

3.62 PLN/m²

Parcel elongation $1: 3$

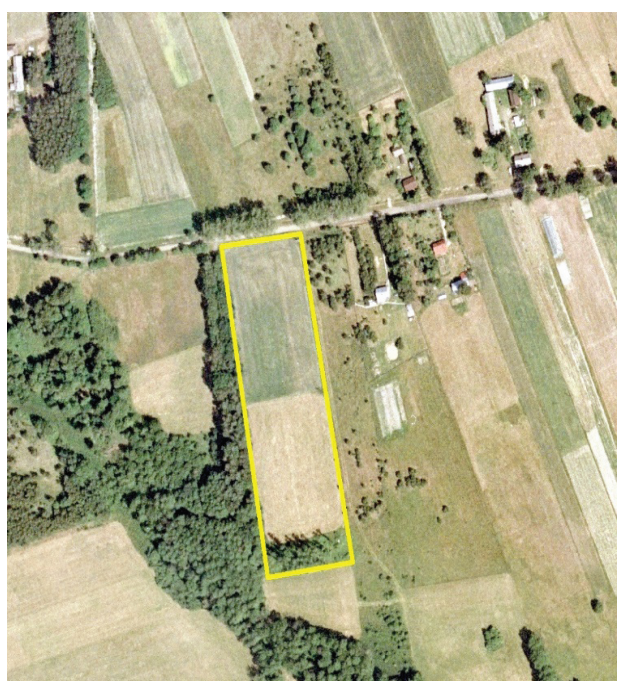

Parcel No. 126/1, Kiczki Drugie village Area 0.3000 ha

Land management $-\mathrm{R}$

1.50 PLN $/ \mathrm{m}^{2}$

Parcel width $-9 \mathrm{~m}$

Parcel elongation - 1: 40

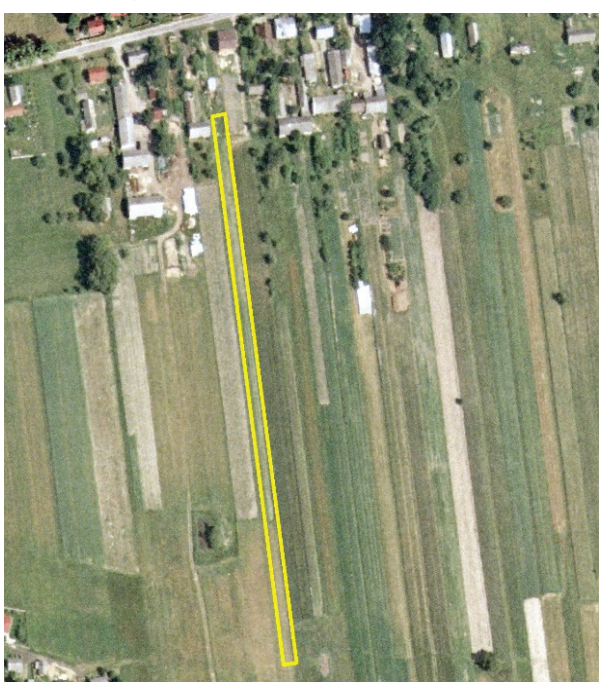

Parcel No. 28/1, Kiczki Drugie village

Area 1.6967 ha

Parcel width $18 \mathrm{~m}$

1.41 PLN $/ \mathrm{m}^{2}$

Parcel elongation $1: 53$

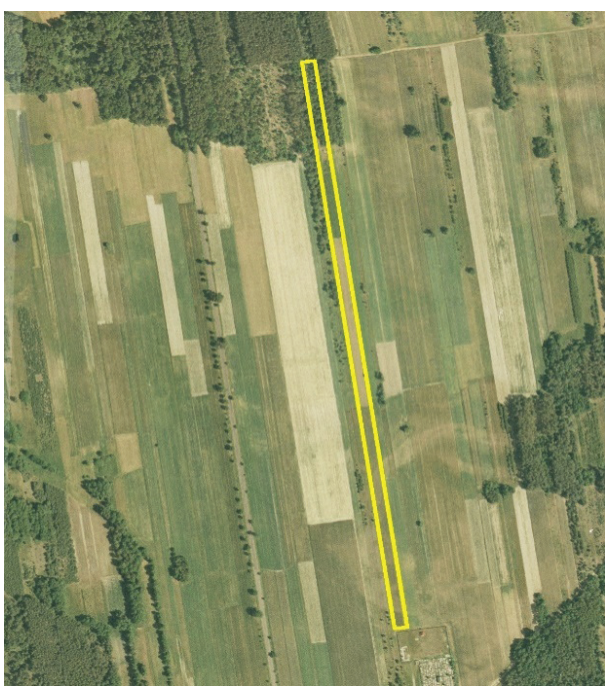

Fig. 6. Example differences in the level of obtained transaction prices for agricultural land depending on parcel width and elongation

Source: own elaboration based on data from the land and mortgage register and data from the property price and value register. 


\section{Conclusions}

The following conclusions were drawn and based on the performed study:

1. In the analysed market of agricultural land, unitary prices of land are largely varied, and their amount frequently does not reflect their market value.

2. In areas with defective spatial structure, parcels distinguished by proper width and elongation are particularly valuable due to the reduced costs of agricultural production.

3. The bonitation value parameter, usually having the most substantial effect on the variability of prices of arable land, is a less significant parameter for the analysed market than those specified above.

4. The coefficient of variability on the prices of agricultural land in the southern part of the Cegłów area amounted to an annual average of $10.4 \%$, and is considerably lower than for arable land at the national scale $-17.7 \%$. This is caused by the low agricultural attractiveness of land resulting from its defective spatial structure.

5. Due to the unfavourable spatial conditions inhibiting the development of the agricultural function, the land turnover in the analysed market is determined by the demand by inhabitants for space for residential and holiday development, and investment plans resulting from the implemented policy in the area. Notice that the process is restricted, because parcels with unfavourable shape (narrow, long) are also less attractive for the purposes of development.

6. In the case of agricultural land, evident signs of leasing and uniform management of contiguous parcels can be observed. This informally solves the difficulties resulting from the unfavourable structure of parcels. As a result, the owners of arable land obtaining income from non-agricultural activities are not interested in selling their property, for example due to the fact that they obtain a low, but regular income from leasing and direct subsidies.

\section{References}

ArcGIS 10.1 Help Library. Retrieved May 18, 2015, from http://resources.arcgis.com.

Central Statistical Office (2014). Statistical yearbook of agricultural. Warsaw: Central Statistical Office. 
Central Statistical Office (2013). Rural areas. Agricultural census 2010. Warsaw: Central Statistical Office \& Statistical Office in Olsztyn.

Ciaian, P., Kancs, D., Swinnen, J., Van Herck, K. \& Vranken, L. (2012). Sales Market Regulations for Agricultural Land in EU Member States and Candidate Countries. Factor Markets Working Paper, 14: 1-29.

Foryś, I. \& Putek-Szeląg, E. (2008). Reasons for investing in agricultural land based on the example of resources of AWRSP and ANR in the Zachodniopomorskie Region. Studia i Materiały Towarzystwa Naukowego Nieruchomości, 16(4), 37-46.

Hozer, J., Kokot, S. \& Kuźmiński, W. (2002). Methods of statistical analysis of the market in the valuation of real estate. Warsaw: The Polish Federation of Valuers' Associations.

Jędrejek, A., Woch, F. \& Szymański, L. (2014). Assessment of the fragmentation of agricultural farms for the determination of the extent of consolidation works in Poland. Przegląd Geodezyjny, 10: 3-10.

Laskowska, E. (2011). Investing in the Polish market of agricultural land. Roczniki Nauk Rolniczych - seria G, 98 (3), 150-159.

Ministry of Agriculture and Food Economy (1999). Coherent structural policy of development of rural areas and agriculture. Document approved by the Council of Ministers on 13 July 1999, Warsaw.

Noga, K. (2001). Methodology of planning and implementation of consolidation works and land exchange in a complex approach. Cracow: Hugo Kołłątaj Agriculture University in Cracow.

Report of Bank BGŻ (2014). State and perspectives of development of the market of agricultural and arable land in Poland in 2014. Warsaw: Bank BGŻ.

Swinnen, J., Ciaian, P. \& Kancs, D. (2008). Study on the Functioning of Land Markets in the EU Member States under the Influence of Measures Applied under the Common Agricultural Policy. Final Report. Brussels: Centre for European Policy Studies.

The Agency for Restructuring and Modernisation of Agriculture. Average prices of land according to the Central Statistical Office, Retrieved May 18, 2015, from www.arimr.gov. pl/dla-beneficjenta/srednie-ceny-gruntow-wg-gus.html.

Woch, F. (2006). Complex agricultural and forest land consolidation and its environmental impact. Puławy: IUNG-PIB.

Woch, F. (2013). State and directions of structural changes in rural areas in Poland. In Conference 'Effect of the modern agricultural policy on the possibilities of development of rural areas', 11-12 September 2013, Puławy. 
